\title{
EFFECTS OF TRADE FLOW LIBERALIZATION: CASE OF ASEAN, NAFTA \& MERCOSUR
}

\section{Hasan Mahmutović Alem Merdić}

University of Zenica, Faculty of Economics, Bosnia and Herzegovina

\author{
Scientific review paper
}

\begin{abstract}
An important factor and the inescapable link of the globalization process are economic integrations, which by the liberalization of trade flows contributes significantly to the interconnection of countries, thus directly affecting the enhancement of the value of macroeconomic parameters at the level of the formed integration. The aim of this paper is to examine the effects of economic integration on the example of ASEAN, NAFTA and MERCOSUR integration, which, along with the European Union, represent the most relevant integrations in the world. The analysis showed, as a consequence of the integration, increased volume of trade exchange, increased FDI level and achieved real economic growth on the level of integration. However, the analysis has shown, in particular in the ASEAN area, that there is still a problem of uneven distribution of income and fairer implementation of regional policy, in order to integrate growth generated into the development of less developed areas.
\end{abstract}

Key words: effects of economic integration, ASEAN, NAFTA, MERCOSUR, regional policy ${ }^{2}$ JEL: F 15

\section{INTRODUCTION}

The development of the theory of international economics and economic integration, on the one hand, and the success of regional integration processes in the context of enhancing economic variables, on the other hand, contributed to the formation of numerous regional integrations, which were primarily established with the aim of absorbing positive economic effects arising from liberalization of goods flows and services, and then with a number of other positive effects (such as political, military, institutional, etc.) resulting in stronger co-operation between member states of a particular integration.

\footnotetext{
${ }^{1}$ Correspodence to:

Hasan Mahmutović, PhD, University of Zenica, Faculty of Economics, Bosnia and Herzegovina

Phone: +387 61912531

E-mail: hasanmahmutovic@hotmail.com

${ }^{2}$ The publication of this paper is an integral part of the realization of the project "Situation and perspectives of economic convergence / divergence of Bosnia and Herzegovina towards the EU" realized with the help of the Federal Ministry of Education and Science of the Federation of Bosnia and Herzegovina, with the aim of analyzing the effects on the level of the formed integrations and assessing potential effects in economic integration of Bosnia and Herzegovina.
} 
The current analysis of the effects of various regional integration has shown that there is inevitably a real growth of the economy at the level of integration established, but that all available capacities, knowledge and energy should be directed to reduce uneven development. The key question is no longer whether regional opening is necessary, as well as linking and building economic and other content that are of interest to the contemporary world, but to make regional and global economic relations more honest and humane and attractive to all participants (Bogunović, 2011).

By default, any form of economic integration will not bring benefits to all integrative process participants if a potential integration member is not ready to integrate, with maximum use of comparative advantages, and prepared internal forces to cope with competitive pressures coming from member states. Therefore, the realization of economic motives of integration, which are reflected in the advancement of economic activity through increased productivity, innovation and technological progress, the mobility of production factors, and ultimately better distribution of wealth and growth of living standards, must be supported by structural changes and adequate preparation not only for formal membership, but also for the substantive and positive economic integration of the country. Both theoretical and empirical evidence has shown that economic integration has positive effects, which does not question the need for integration of countries, but the will of the developed member states is a problem that the integration will be effective for all members by running a just regional policy that will result in a humane and just distribution of wealth, therefore the convergence of members of the integration.

This paper analyzes the effects of three multilateral regional economic integrations, which, together with the European Union, represent the most significant economic integration in the world, ie the axis of the development of world trade relations, namely:

1. ASEAN - Association of Southeast Asian Nations

2. NAFTA - North American Free Trade Agreement

3. MERCOSUR - Mercado Comun del Sur

\section{METHODS}

The study of the effects of interconnection in these integrations was done by applying qualitative and quantitative research methods. The qualitative methods used in the paper are: deduction, induction, analysis, synthesis and concretization as a form of specialization. In addition to these methods, methods of comparing economic parameters at the level of connected countries were used before and after interconnection, and analytical statistics for the purpose of making conclusions about the effects of specific integration.

\section{RESEARCH}

ASEAN - The Association of Southeast Asian Nations was founded on August 8, 1967. by signing the Bank Declaration by 5 Southeast Asian countries: Indonesia, Malaysia, the Philippines, Singapore and Thailand, which are considered ASEAN's founders. Subsequently, the following Southeast Asian countries were joined by Brunei (1984), Vietnam (1995), Laos and Myanmar (1997) and Cambodia (1999). ASEAN was established with the intention of countering the obvious offensive communist states in the wake of the Vietnam War and the bipolar balance of power in the world (Turčinović \& Vrcelj, 2010.) In addition to this objective, as defined in the Bank Declaration, the purpose and objectives of ASEAN include the following (adapted: http://asean.org/asean/aboutasean/overview):

1. through joint efforts to accelerate economic growth, social progress and cultural development in the spirit of equality, with the aim of creating the basis for successful development of South East Asia;

2. promotion of regional stability and peace in accordance with the UN Charter;

3. improving common co-operation on issues of mutual interest;

4. mutual cooperation and assistance in research, education, technical and administrative areas;

5. more effective co-operation for exploiting all potentials (agricultural, industrial, and so on);

6. maintaining close co-operation with existing organizations and integrations with similar interests and goals. 
The cooperation of the member countries takes place through the Council of the organizations that comprise the Foreign Minister of the Host Country Council meeting and the ambassadors of the member states. The Chamber has three panels to address significant issues: Economy, Political-Security Council and the socio-cultural council. Significant issues are addressed at the annual summits of the heads of governments and member states, which are held annually. In addition to the summit, ministerial conferences are held twice a year, addressing issues of major importance to ASEAN (Turčinović \& Vrcelj, 2010.). NAFTA - The North American Free Trade Agreement was created as a result of the US, Canada and Mexico Free Trade Establishment negotiations that began in 1991 and resulted in the signing of the Free Trade Agreement on December 17, 1992. This Agreement was put into effect on 1 January 1994, creating one of the world's largest free trade zones. This agreement has laid the foundations for a strong economic growth and prosperity for Canada, the United States and Mexico. From then on, the effects of this integration are reflected in increasing wealth and competitiveness. The basic objective of the NAFTA Agreement is to remove barriers to trade between its members in order to increase the positive effects of integration by increased liberalization and increase the consumer's surplus, which is reflected in the fall in product prices due to the reduction of barriers on the one hand and the increase in the product range, on the other side. Also, positive effects also apply to efficient manufacturers, due to increased market size. Member States' cooperation is geared to adequate competition with other regional integration, notably the EU, but given that NAFTA is only a free trade zone, not a customs union or a common market, it is more appropriate to integrate that integration with the EFTA than with the EU. Each of the member states can independently regulate their trade policy in relation to third countries, which is a lower degree than the EU integration. The NAFTA Group is by its power the largest in the world and implies, in its final and future development projections, facing all the challenges of modernizing international economic and trade relations (FOLSOM, 2004).

MERCOSUR - The Common Market of the South represents the integration that was formed on 29.11.1991. by 4 countries from South America: Brazil, Argentina, Paraguay and Uruguay, and includes the establishment of a free trade zone by signing the Asuncion Treaty. In addition to permanent members, into the integration Venezuela was included in 2012, which has been ratifying full membership since 2006 from Brazil and Paraguay, as well as associated members: Chile, Bolivia, Colombia, Peru and Ecuador. MERCOSUR functions as a customs union with a long-term ambition to create a common market model based on the EU, which was the goal of its founding, but for more than 25 years it has not been realized.

\section{RESULTS}

\section{ASEAN}

ASEAN is the world's third-largest scope with 629 million inhabitants. In 2015, ASEAN made 3.3\% of the world's production. With 3,867 US \$ GDP p.c. in 2015, ASEAN represents the poorest regional integration.

The effects of the ASEAN Agreement are shown in Image 1 . The movement of all key economic indicators within the ASEAN zone shows that integration has resulted in real economic growth and improvement of competitiveness and level of prosperity at the level of integration. 


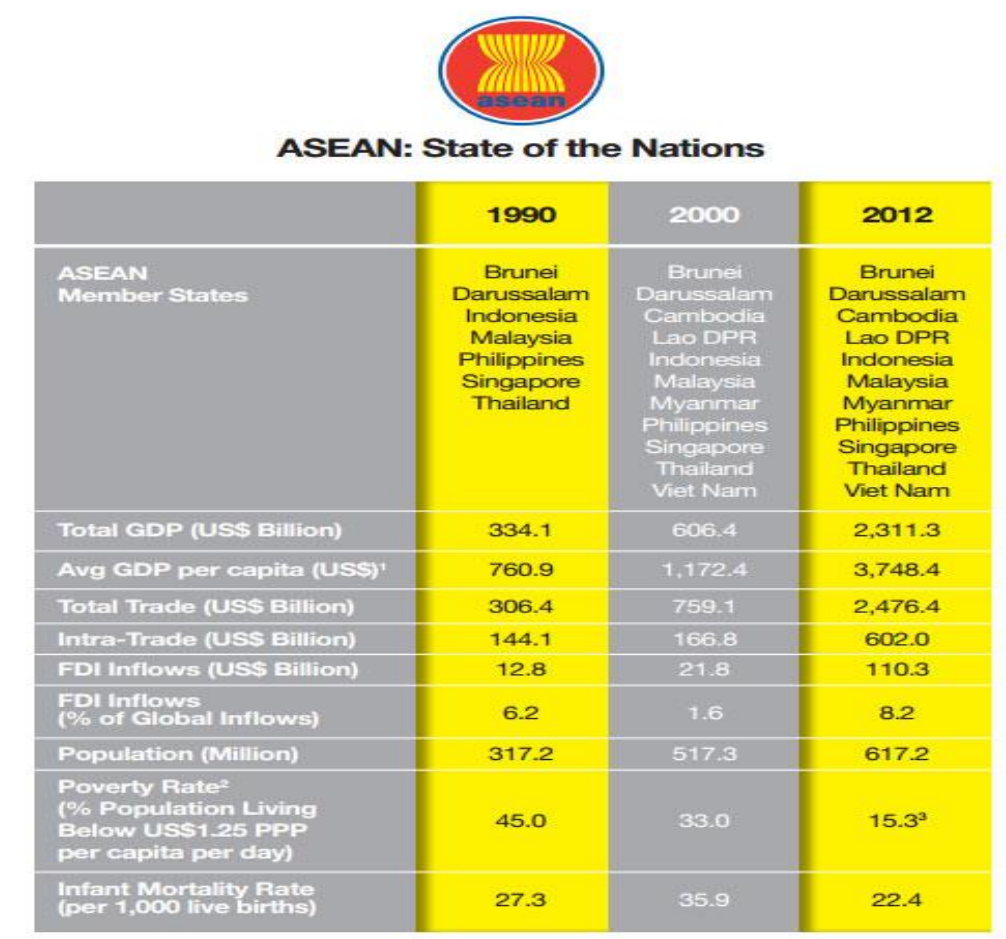

Image 1 The impact of the ASEAN Agreement on Key Economic Indicators for the period 1990 - 2012.

Source: https://aseanup.com/benefits-asean-economic-community-aec/

The data presented in Image 1 best describes the results of interconnection between countries, i.e. liberalization of trade, but the problem remains for the implementation of a more just regional policy. The total GDP on the level of integration between 1990 and 2012 has increased from US \$ 334.1 billion to US \$ 2,311.3 billion, and average GDP per capita increased by approximately 5.5 times. The total trade exchange between related countries at the level of integration was increased by 8 times, foreign direct investment by 10 times.

Neither ASEAN has operated since the uneven distribution of income, as ASEAN Member State Singapore in 2015 had a GDP value per capita of US \$ 52,888, which is more than 15 times more than the average at
ASEAN level. This situation, once again, confirms the fact that the development of underdeveloped (poor) parts of the world is under the control of developed countries and that, by focusing exclusively on the economic motives of integration, the questioning of the process of equalization of regional development is questionable.

\section{NAFTA}

The following table shows the effects of trilateral linking, i.e. the creation of a free trade zone NAFTA, as well as the movement of bilateral trade between the member countries of integration.

Table 1 Effects of the NAFTA Agreement on Trade between Member States (in 000000 \$)

\begin{tabular}{lcccc}
\hline \multicolumn{1}{c}{ Relation } & $\mathbf{1 9 9 3}$ & $\mathbf{2 0 1 5}$ & Nominal growth & Real growth \\
\hline USA-Canada & 199.184 & 518.217 & $160,2 \%$ & $63,5 \%$ \\
USA-Mexico & 85.224 & 481.543 & $465,0 \%$ & $265,0 \%$ \\
Mexico-Canada & 4.052 & 34.344 & $747,6 \%$ & $432,5 \%$ \\
Trilateral trade & 288.460 & 1.034 .104 & $285,5 \%$ & $125,2 \%$ \\
\hline
\end{tabular}

Source: According to data: Mexican Embassy in Canada

The data presented in Table 1 best reflect the effects of trade integration of NAFTA members. In the observed period from 1993 to 2015, the total volume of
US and Canada trade exchanges increased nominally by $160.2 \%$, while real growth was $63.5 \%$, as a consequence of the liberalization of trade in goods and services. 
The volume of trade exchange between the United States and Mexico increased by $465.0 \%$ in nominal terms, i.e. the real growth rate was $265.0 \%$. Although Canada had initially been distorted when it comes to incorporating Mexico into a free trade zone, the easy placement of Mexican market products was a benefit Canada should not miss. The outcomes of trade liberalization are visible in a huge increase in trade between Canada and Mexico by $747.6 \%$ in nominal terms, i.e. a real growth rate of $432.5 \%$. A significant increase in US and Canadian trade exchange with Mexico in relation to their mutual exchange is the consequence of the Canada-US Free Trade Agreement (CUFTA), which was the Free Trade Agreement between the United States and Canada, and was signed in 1989 and was active five years before the signing of the NAFTA Agreement. The total value of trilateral trade for the 22-year NAFTA agreement increased by $285.5 \%$ in nominal terms or by $125.2 \%$ in real terms.

In addition to the increase in the volume of trade at a trilateral level, real GDP per capita growth of all members of the integration has increased. From
1993 to 2015, real GDP p.c. of the US has increased by $39.3 \%$ and in 2015 it amounted $\$ 51.628$. GDP p.c. of Canada rose by $40.3 \%$ in the observed period and in 2015 it was $\$ 50.001$, while real GDP p.c. in Mexico rose by $24.1 \%$ and in 2015 it was $\$ 9,511$ (according to: www.data.worldbank.org). The above data best reflects the benefits of functional integration for all members and represents the confirmation of the existence of scientifically proven benefits of integration.

\section{MERCOSUR}

The analysis of MERCOSUR's economic indicators is presented in Table 2, showing comparative trends of key economic indicators at the beginning of integration with indicators in 2012. According to data from Table 2, GDP p.c. of Argentina in 1990 amounted to $\$ 5,180$, and after 10 years of MERCOSUR membership it was $\$ 9,209$, which is less than twice the increase, the increase to $\$ 14,667$ by 2012 represents almost 3 times higher GDP p.c. in relation to its value at the moment of establishment of integration.

Table 2 MERCOSUR's Effects on the Movement of GDP p.c. and foreign trade exchange

\begin{tabular}{ccccccccc}
\hline \multirow{2}{*}{ Economic Indicator } & \multicolumn{2}{c}{ Argentina } & \multicolumn{2}{c}{ Brazil } & \multicolumn{2}{c}{ Uruguay } & \multicolumn{2}{c}{ Paraguay } \\
\cline { 2 - 9 } & $\mathbf{1 9 9 0}$ & $\mathbf{2 0 1 2}$ & $\mathbf{1 9 9 0}$ & $\mathbf{2 0 1 2}$ & $\mathbf{1 9 9 0}$ & $\mathbf{2 0 1 2}$ & $\mathbf{1 9 9 0}$ & $\mathbf{2 0 1 2}$ \\
\hline GDP p.c. \$ & 5.180 & 14.667 & 3.107 & 11.315 & 3.302 & 14.728 & 1.167 & 3.729 \\
Export (mil \$) & 12.353 & 80.927 & 31.413 & 242.580 & 1.708 & 8.709 & 959 & 7.282 \\
Importation (mil \$) & 4.077 & 68.508 & 22.460 & 233.368 & 1.415 & 11.652 & 1.350 & 11.555 \\
\hline
\end{tabular}

Source: customized according to: Bastos, A. L., others, Analysis of the Evolution of Social and Economic Indicators of the Mercosur's Members: 1980-2012, World Academy of Science, Engineering and Technology International Journal of Social, Behavioral, Educational, Economic, Business and Industrial Engineering Vol:10, No:6, 2016

The data from Table 2 show that all permanent MERCOSUR members by 2012 realized GDP growth p.c. by 3 to 5 times in relation to the GDP level p.c. in the year before integration. Also, there has been an increase in the trade volume between 5 and 8 times the size before integration. Integration has had positive effects on Argentina and Brazil, as trade surplus has increased, with Uruguay and Paraguay having negative effects, as the deficit in the trade balance has increased, confirming once again that integration leads to the improvement of economic indicators at the level of integration, but there is always a problem of distribution through the integration of established wealth, ie even distribution of income, which is an imperfect gap in the scientific study of regional (non) equality and leaves room for ambitious and serious researchers to create adequate models of even distribution of wealth.

\section{CONCLUSION}

The complete, above presented analysis of economic integration from the aspect of economic parameters does not in any way call into question the need for integration, as the macroeconomic parameters in the integrated space will be improved. However, the question arises as to how the dispersion of the created wealth will be carried out, and whether integration leads to rich prosperity and the introduction of less competitive countries in function of the additional development of more developed members of the integration. 
It is hard to expect that a developed country, joining the integration processes, will advocate for a just regional policy. In support to this, the fact is that even in developed countries in the internal plan, the principles of balanced regional development have not been respected, so the question is how some countries will strive for a fair regional policy at the international level when there are regional diverging development trends on the internal plan. It is important to conclude that any integration does not have to mean generating positive economic results but that economic integration can contribute to the economic development of a Member State if it achieves the appropriate degree of competitiveness on the internal plan and exploits its comparative advantages in the integrated space.

The presented analysis of the effects of integration in the case of ASEAN and MERCOSUR showed all the possible drawbacks, i.e. the negative effects of integration. In the case of ASEAN, Singapore has 15 times higher GDP per capita compared to the average on the level of integration. This is also a challenge for creators of a more just regional policy model, as well as those in the process of integration, how to create a more equitable distribution model through the integration of created wealth, and how to apply the created model for the purpose of realizing the goals of regional policy. In the case of MERCOSUR, the negative effects of integration were generated by
Uruguay and Paraguay, as there was an increase in the deficit in the balance of trade, resulting from a low level of competitiveness in relation to Brazil and Argentina, where the value of surplus trade balance in relations with Uruguay and Paraguay rose, i.e. in trade relations at the level of formed integration. This confirms once again that an appropriate level of competitiveness of the domestic economy needs to be developed before integration, so that the economy can deal with competing forces at the level of integration rather than go into integrative processes at all costs, as it will contribute to the generation of negative effects of integration..

\section{REFERENCES}

Bastos, A. L., others (2016). Analysis of the Evolution of Social and Economic Indicators of the Mercosur's Members: 1980-2012. World Academy of Science. Engineering and Technology International Journal of Social. Behavioral, Educational, Economic, Business and Industrial Engineering Vol:10, No:6.

Bogunović, A. (2011). Regionalna ekonomika i politika. Ekonomski fakultet. Zagreb.

FOLSOM, R. (2004). NAFTA and Free Trade in the Americans in o Nulshell. St. Paul. Minesota.

http://asean.org/asean/about-asean/overview

Turčinović, F., Vrcelj, N. (2010). Postglobalizam i ekonomske integracije. Megatrend Univerzitet. Beograd.

www.data.worldbank.org 